\title{
Evaluation of serum HGF and CK18 levels in patients with esophageal cancer
}

\author{
N. Kilic-Baygutalp ${ }^{1}$, N. Ozturk ${ }^{1}$, E. Orsal-Ibisoglu², B. Gündogdu ${ }^{3}$, \\ F.B. Ozgeris ${ }^{1}$, N. Bakan ${ }^{1}$, E. Bakan ${ }^{1}$ and A.F. Kilic ${ }^{4}$ \\ ${ }^{1}$ Department of Medical Biochemistry, School of Medicine, Ataturk University, \\ Erzurum, Turkey \\ ${ }^{2}$ Department of Nuclear Medicine, School of Medicine, Ataturk University, \\ Erzurum, Turkey \\ ${ }^{3}$ Department of Medical Pathology, School of Medicine, Ataturk University, \\ Erzurum, Turkey \\ ${ }^{4}$ Department of Internal Medicine, School of Medicine, Ataturk University, \\ Erzurum, Turkey \\ Corresponding author: N. Kilic-Baygutalp \\ E-mail: eczbaygutalp80@gmail.com \\ Genet. Mol. Res. 15 (3): gmr. 15038583 \\ Received February 29, 2016 \\ Accepted April 11, 2016 \\ Published August 29, 2016 \\ DOI http://dx.doi.org/10.4238/gmr. 15038583 \\ Copyright (C) 2016 The Authors. This is an open-access article distributed under the terms of \\ the Creative Commons Attribution ShareAlike (CC BY-SA) 4.0 License.
}

ABSTRACT. Cytokeratins are thought to play a role in apoptosis. Cytokeratin 18 (CK18) is involved in the formation of intracellular cytoskeleton, and has been considered a promising apoptosis marker in gastrointestinal carcinomas. Growth factors, including hepatocyte growth factor (HGF), may provide a microenvironment for malignant cells. In this study, we aimed to compare serum HGF and CK18 levels between esophageal squamous cell carcinoma patients and healthy controls. The study included 41 adult patients (20 male, 21 female) diagnosed with esophageal squamous cell carcinoma, with a mean age of $63.54 \pm 10.88$ years (range, 41-82 years). We also recruited 39 age 
and gender-matched healthy control subjects. Venous blood samples were taken; serum HGF and CK18 concentrations were determined via ELISA. Results indicated that serum HGF levels were higher in patients $(1.37 \pm 0.63 \mathrm{ng} / \mathrm{mL})$ as compared to the healthy subjects $(0.41$ $\pm 0.29 \mathrm{ng} / \mathrm{mL})$. Similarly, serum CK18 levels were higher in the patient group $(2.53 \pm 1.33 \mathrm{ng} / \mathrm{mL})$ than in the control group $(0.34 \pm 0.23$ $\mathrm{ng} / \mathrm{mL})(\mathrm{P}<0.001)$. In addition, serum HGF and CK18 levels were positively correlated with metastasis stage, tumor stage, and disease stage of esophageal squamous cell carcinoma. To our knowledge, this is the first study to evaluate serum HGF and CK18 levels in patients with esophageal squamous cell carcinoma. The results suggest that serum CK18 and HGF levels may be used as prognostic and disease monitoring biomarkers of esophageal squamous cell carcinoma.

Key words: HGF; CK18; Esophageal squamous cell carcinoma; Biomarker

\section{INTRODUCTION}

Esophageal squamous cell carcinoma (ESCC) is a sub-type of human epithelial cancer, and is one of the most lethal carcinomas worldwide (Guo et al., 2008). As the disease is usually diagnosed in late stages, it has poor prognosis with high metastasis rates. The 5-year survival rates vary between 15 and 25\% (Pennathur et al., 2013). Interactions between genetic and environmental factors are involved in the pathogenesis of this disease (Parker et al., 2010). Surgical operation, preoperative and postoperative adjuvant chemotherapy, as well as preoperative chemoradiotherapy are the most common treatment options for ESCC.

Histopathological examination of resected tissues is the most reliable evidence for the diagnosis of ESCC, yet it is not applicable in non-operated cases. Therefore, the ability to identify biomarkers for early diagnosis of ESCC may improve disease prognosis and survival of ESCC patients.

Cytokeratins (CKs) are a family of intermediate filament proteins that form the intracellular cytoskeleton of epithelial cells (Chu and Weiss, 2002). There are 20 different CK subtypes; CKs with acidic properties are classified as Type I CKs (CK9-20), and those with neutral basic properties are known as Type II CKs (CK1-8). CK18 is a Type I CK, and is a component of the cell's structural network that extends from the surface of the nucleus to the cell membrane. CK18 is involved in important cellular processes including apoptosis, mitosis, cell cycle progression, and cell signaling under normal physiological conditions. Circulating CK18 fragments have been accepted as an epithelial marker for diagnostic histopathological examinations, and has been suggested to affect tumor cell behaviors (Weng et al., 2012).

CK18 is reported to be expressed in various cancerous tissues including ESCC (Kalantari, 2009). Its expression has also been detected in human lung adenocarcinoma cell lines, melanoma, ESCC, as well as some mouse carcinomas (Zhang et al., 2011). CK18 expression patterns have been reported to be associated with lymph node metastasis in ESCC. Furthermore, it has been suggested that CK18 expression and distribution pattern could be used as predictive biomarkers of disease progression (Cintorino et al., 2001).

Human growth factor (HGF) plays a potential role in the progression of various types

Genetics and Molecular Research 15 (3): gmr.15038583 
of tumors, and is overexpressed in ESCC (Saeki et al., 2002). c-Met is the transmembrane tyrosine kinase receptor of HGF, and possesses similar oncogenic properties. It has been suggested that the HGF/c-Met signaling pathway is associated with malignant cancers, and may be involved with cancer metastasis (Anderson et al., 2006). Conversely, recent studies have shown that HGF may exhibit therapeutic effects on some diseases such as human silicosis (Liu et al., 2015) and myocardial ischemic injury (Wang et al., 2014).

The possible role of HGF and CK18 in the development and progression of ESCC remains unclear. This study aimed to evaluate serum CK18 and HGF levels in ESCC patients, and to investigate the relationship between ESCC and these candidate biomarkers.

\section{MATERIAL AND METHODS}

The study included 41 Caucasian patients (female/male: 21/20) diagnosed with ESCC in our clinic as well as 39 healthy subjects (female/male: 20/19).

Subject demographics, as well as clinical and laboratory findings were recorded by the same researcher. Venous blood samples were collected in the morning following an overnight fast. Sera were obtained and stored at $-80^{\circ} \mathrm{C}$ until analysis. Serum CK18 and HGF levels were measured in all subjects using the human Cusabio ELISA kits (CSB-E09172h for CK18 and CSB-E04573h for HGF, Wuhan, China). Intra-assay and interassay coefficient variations of the kit were $<8$ and $<10 \%$, respectively.

ESCC of the thoracic esophagus was confirmed by histopathological examination on biopsy materials obtained via endoscopy. The patients included in the study had no history of other cancers. The clinical distribution of the patients was as follows: 18 patients $(43.90 \%)$ underwent surgical resection, 2 patients $(4.88 \%)$ underwent surgical resection followed by chemoradiation therapy, and 21 patients $(51.22 \%)$ underwent chemoradiaton therapy.

Approval for the study was granted by the local Ethics Committee, and all procedures were performed in accordance with the Helsinki Declaration of 1975, as revised in 2000.

\section{Statistical analysis}

Data were analyzed using the SPSS 20.0 software package (SPSS Inc., Chicago, IL, USA). Results are reported as means \pm standard deviation. Data conformation to the normal distribution was evaluated with the Kolmogorov-Smirnov test. Since normal distribution was confirmed in both HGF and CK18 levels, differences between the groups were analyzed with the independent samples $t$-test and the one-way ANOVA. $\mathrm{P}<0.05$ in a $95 \%$ confidence interval was accepted as being statistically significant.

\section{RESULTS}

The demographic characteristics and serum CK18 and HGF levels of both groups are displayed in Table 1. No statistically significant difference was observed between the patient and control groups with respect to age or gender. Results showed significantly elevated serum CK18 levels in patients with esophageal cancer $(2.53 \pm 1.33 \mathrm{ng} / \mathrm{mL})$ as compared to healthy controls $(0.34 \pm 0.23 \mathrm{ng} / \mathrm{mL})(\mathrm{P}<0.001)$. Similarly, serum HGF levels were significantly higher in the patient group $(1.37 \pm 0.63 \mathrm{ng} / \mathrm{mL})$ than in the control group $(0.41 \pm 0.29 \mathrm{ng} / \mathrm{mL})$ $(\mathrm{P}<0.001)$. 
Table 1. Demographics and serum CK18 and HGF levels in the patient and control groups.

\begin{tabular}{l|c|c|c}
\hline & Patient group $(\mathrm{N}=41)$ & Control group $(\mathrm{N}=39)$ & P value \\
\hline Age $($ years, means \pm SD) & $63.54 \pm 10.88$ & $61.82 \pm 9.87$ & 0.234 \\
\hline Gender $(\mathrm{N}$, female/male) & $21 / 20$ & $20 / 19$ & 0.83 \\
\hline CK18 $(\mathrm{ng} / \mathrm{mL})$ & $2.53 \pm 1.33$ & $0.34 \pm 0.23$ & $<0.001$ \\
\hline HGF $(\mathrm{ng} / \mathrm{mL})$ & $1.37 \pm 0.63$ & $0.41 \pm 0.29$ & $<0.001$ \\
\hline
\end{tabular}

The statistical evaluation of serum CK18 and HGF levels and clinicopathological features are shown in Table 2. When serum CK18 and HGF levels were evaluated according to the clinicopathological features, we found that different clinicopathological features correlated with different serum CK18 and HGF levels, with the exception of node stage (Table 2). It was observed that serum HGF and CK18 levels were significantly higher in patients with cancer metastasis as compared to those with no metastasis. In addition, higher serum HGF and CK18 levels were found in patients at the T4 tumor stage as compared to those at the T3 tumor stage. We did not include data from two patients at the T2 tumor stage in our statistical analysis, as the variances were non-homogeneous.

Table 2. Serum CK18 and HGF levels for each disease parameter in ESCC patients.

\begin{tabular}{|c|c|c|c|c|}
\hline Disease parameters & CK18 (ng/mL) & $P$ value & HGF (ng/mL) & $P$ value \\
\hline Tumor stage & & 0.001 & & $<0.001$ \\
\hline $\mathrm{T}_{3}(\mathrm{~N}=24)$ & $1.89 \pm 1.11$ & & $1.09 \pm 0.39$ & \\
\hline $\mathrm{T}_{4}(\mathrm{~N}=15)$ & $3.42 \pm 1.20$ & & $1.80 \pm 0.58$ & \\
\hline Metastatis stage & & $<0.001$ & & $<0.001$ \\
\hline $\mathrm{M}_{0}(\mathrm{~N}=13)$ & $1.06 \pm 0.23$ & & $0.78 \pm 0.15$ & \\
\hline $\mathrm{M}_{1 \mathrm{a} / \mathrm{lb}}(\mathrm{N}=28)$ & $3.21 \pm 1.06$ & & $1.65 \pm 0.47$ & \\
\hline Node stage & & 0.566 & & 0.338 \\
\hline $\mathrm{N}_{0}(\mathrm{~N}=3)$ & $2.17 \pm 1.53$ & & $1.16 \pm 0.44$ & \\
\hline $\mathrm{N}_{1}(\mathrm{~N}=38)$ & $2.49 \pm 1.32$ & & $1.41 \pm 0.67$ & \\
\hline Stage & & $<0.001$ & & $<0.001$ \\
\hline Stage III $(\mathrm{N}=25)$ & $0.99 \pm 0.23$ & & $0.73 \pm 0.14$ & \\
\hline Stage IV $(\mathrm{N}=16)$ & $3.09 \pm 1.01$ & & $1.60 \pm 0.42$ & \\
\hline
\end{tabular}

Pearson correlation analysis showed a strong positive correlation between serum CK18 and HGF levels in the patient group $(\mathrm{P}<0.001, \mathrm{r}=0.522)$ (Figure 1). The correlation coefficients and $\mathrm{P}$ values for all the parameters are given in Table 3.

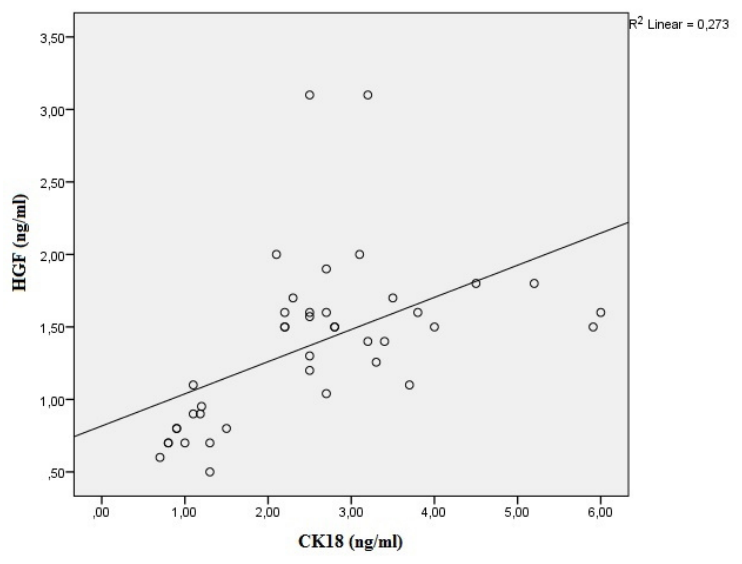

Figure 1. Correlation between serum HGF and CK18 levels in ESCC patients.

Genetics and Molecular Research 15 (3): gmr.15038583 


Table 3. Correlations between serum CK18/ HGF and disease parameters.
\begin{tabular}{l|c|c}
\hline Disease parameters & $\mathrm{CK} 18$ & HGF \\
\hline Metastatis stage & $(\mathrm{P}<0.001, \mathrm{r}=0.753)$ & $(\mathrm{P}<0.001, \mathrm{r}=0.721)$ \\
\hline Node stage & $(\mathrm{P}=0.020, \mathrm{r}=0.363)$ & $(\mathrm{P}=0.009, \mathrm{r}=0.400)$ \\
\hline Tumor stage & $(\mathrm{P}=0.014, \mathrm{r}=0.379)$ & $(\mathrm{P}<0.001, \mathrm{r}=0.633)$ \\
\hline Stage & $(\mathrm{P}<0.001, \mathrm{r}=0.677)$ & \\
\hline
\end{tabular}

$\mathrm{P}=$ test statistic $\mathrm{P}$ value; $\mathrm{r}=$ correlation coefficient.

\section{DISCUSSION}

ESCC is a type of cancer that exhibits high mortality rate; by the time of disease diagnosis, the cancer would have already reached advanced stages. Therefore, the identification and usage of clinical biomarkers for ESCC is an important field of research.

In this study, we aimed to analyze serum CK18 and HGF levels in ESCC patients, and to evaluate the relationship between these biomarkers and disease activity. Our results showed that serum CK18 and HGF levels were significantly higher in ESCC patients with advanced tumor stages (pT3 and pT4) as compared to healthy controls. Furthermore, serum CK18 and HGF levels also correlated with each other. CK18 and HGF levels were significantly higher in advanced stages of ESCC, which include manifestation of distinctive clinicopathological features such as metastasis, advancing tumor stages, and advancing ESCC stages. In addition, as serum CK18 and HGF levels were found to be associated with cancer metastasis, evaluation of serum HGF and CK levels in patients during biopsy may be beneficial for predicting metastasis risk or tumor staging of ESCC patients without using radiological imaging techniques.

CK18 is highly expressed in ESCC patients, and studies have shown that upregulated expression of this protein is associated with poor diagnosis in squamous cell carcinomas (Fillies et al., 2006). CK18 is normally expressed in non-cancerous glandular, transitional and hepatocyte epithelium, but not in squamous stratified epithelium (Trask et al., 1990; Schüssler et al., 1992). Therefore, the CK18 protein may serve as a potential biomarker for the diagnosis and prognosis of ESCC. In a large immunohistochemical study conducted on 210 resected specimens from ESCC patients, CK18 and its co-expressed complementary subunit CK8 were reported to be highly expressed in cancerous squamous epithelium of the esophageal glands; this expression was correlated with progression of ESCC. Researchers have suggested that CK18 may be useful in selecting treatment strategies for ESCC (Makino et al., 2009). Another large study conducted on 219 gastric or gastro-esophageal cancer patients ( 97 patients who received pre-operative platinum-based chemotherapy and 122 patients who received no neoadjuvant chemotherapy) showed that CK18 was commonly (92.6\%) expressed in gastro-esophageal tumors (Fareed et al., 2012). Micrometastasis is considered a key step in cancerogenesis, and the detection of micrometastasis is crucial in deciding whether or not adjuvant therapy is necessary following surgery (Noguchi et al., 2003). Thus, the CK18 protein is an important factor in determining the progression of ESCC.

Studies have indicated that factors produced by the extracellular matrix, which alter the tumor microenvironment, may change carcinoma behavior and affect its prognosis. Cancerassociated fibroblasts have such a role in tumorigenesis (Bhowmick et al., 2004), and are present in various types of squamous cell carcinomas including ESCC (Iwazawa et al., 1996; Okawa et al., 2007). Previous studies have demonstrated that cancer-associated fibroblasts isolated from mammary and prostate tumors promote tumorigenesis in normal epithelium.

Genetics and Molecular Research 15 (3): gmr.15038583 
Conversely, fibroblasts from normal tissues converted tumorigenic skin and prostate epithelial cells into morphologically benign lesions (Cooper and Pinkus, 1977; Olumi et al., 1999).

HGF is a mesenchymal cytokine, and acts as a potent mitogen and pro-motility agent for epithelial cells by activating mitogenesis, morphogenesis, and angiogenesis (Bussolino et al., 1992; Grant et al., 1993). The term scatter factor, another term for HGF, was named for the ability of HGF to induce hepatocyte scattering, similar to a mitogen (Nakamura et al., 1986; Stoker et al., 1987). This angiogenic cytokine exerts its effects on epithelial tissues through a paracrine mode of action. c-Met is the HGF receptor on epithelial cells, and belongs to the tyrosine kinase family of receptors. Aberrant $\mathrm{HGF} / \mathrm{cMET}$ activation is involved in various types of carcinomas including ESCC. Serum HGF levels have been evaluated and reported to be related to poor prognosis in prostate cancers (Ren et al., 2005), lung cancers (Takada et al., 1995) and ESCC (Grugan et al., 2010). HGF levels have also been associated with advanced tumor stage and metastasis in ESCC patients, and in vitro studies have demonstrated that HGF plays a role in promoting invasion, migration, and metastasis of ESCC cells (Grugan et al., 2010). However, these effects could not be determined in normal epithelial cells, possibly due to the absence of c-Met on normal epithelial surface. It has been suggested that inactivating HGF using antibodies and/or inhibiting the HGF/c-Met signaling pathway may be a potential therapeutic approach for regulating the angiogenesis and metastasis of tumorigenic tissues (Grugan et al., 2010). There are promising targeted therapy strategies that have demonstrated favorable results in both completed and ongoing preclinical studies (Hack et al., 2014). The results of these studies reveal the need for biomarkers that are not only used for diagnosis and prognosis, but also for determining patients who are more prone to benefit from targeted therapies.

Results from the study show that CK18 and HGF may be valuable biomarkers that can be used to determine pathological staging, disease prognosis, as well as to monitor treatment responses and disease recurrence in ESCC. To the best of our knowledge, this is the first study evaluating serum levels of CK18 and HGF in patients with ESCC. However, our preliminary study lacks patients with early stage tumors. Further studies need to be conducted on ESCC patients with both early and advanced tumor stages in order to fully elucidate the mechanisms of action of CK18 and HGF on the development and progression of ESCC. Determining cutoff levels for different disease stages may lead to clinical use of serum CK18 and HGF levels as disease monitoring parameters.

\section{Conflicts of interest}

The authors declare no conflict of interest.

\section{ACKNOWLEDGMENTS}

The authors would like to thank to Caroline Jane Walker for English language editing of the article.

\section{REFERENCES}

Anderson MR, Harrison R, Atherfold PA, Campbell MJ, et al. (2006). Met receptor signaling: a key effector in esophageal adenocarcinoma. Clin. Cancer Res. 12: 5936-5943. http://dx.doi.org/10.1158/1078-0432.CCR-06-1208

Bhowmick NA, Neilson EG and Moses HL (2004). Stromal fibroblasts in cancer initiation and progression. Nature 432:

Genetics and Molecular Research 15 (3): gmr.15038583 
332-337. http://dx.doi.org/10.1038/nature03096

Bussolino F, Di Renzo MF, Ziche M, Bocchietto E, et al. (1992). Hepatocyte growth factor is a potent angiogenic factor which stimulates endothelial cell motility and growth. J. Cell Biol. 119: 629-641. http://dx.doi.org/10.1083/ jcb.119.3.629

Chu PG and Weiss LM (2002). Keratin expression in human tissues and neoplasms. Histopathology 40: 403-439. http:// dx.doi.org/10.1046/j.1365-2559.2002.01387.x

Cintorino M, Tripod SA, Santopietro R, Antonio P, et al. (2001). Cytokeratin expression patterns as an indicator of tumour progression in oesophageal squamous cell carcinoma. Anticancer Res. 21 (6A): 4195-4201.

Cooper M and Pinkus H (1977). Intrauterine transplantation of rat basal cell carcinoma as a model for reconversion of malignant to benign growth. Cancer Res. 37: 2544-2552.

Fareed KR, Soomro IN, Hameed K, Arora A, et al. (2012). Caspase-cleaved cytokeratin-18 and tumour regression in gastro-oesophageal adenocarcinomas treated with neoadjuvant chemotherapy. World J. Gastroenterol. 18: 19151920. http://dx.doi.org/10.3748/wjg.v18.i16.1915

Fillies T, Werkmeister R, Packeisen J, Brandt B, et al. (2006). Cytokeratin 8/18 expression indicates a poor prognosis in squamous cell carcinomas of the oral cavity. BMC Cancer 6: 10. http://dx.doi.org/10.1186/1471-2407-6-10

Grant DS, Kleinman HK, Goldberg ID, Bhargava MM, et al. (1993). Scatter factor induces blood vessel formation in vivo. Proc. Natl. Acad. Sci. USA 90: 1937-1941. http://dx.doi.org/10.1073/pnas.90.5.1937

Grugan KD, Miller CG, Yao Y, Michaylira CZ, et al. (2010). Fibroblast-secreted hepatocyte growth factor plays a functional role in esophageal squamous cell carcinoma invasion. Proc. Natl. Acad. Sci. USA 107: 11026-11031. http://dx.doi.org/10.1073/pnas.0914295107

Guo Y, Chen Z, Zhang L, Zhou F, et al. (2008). Distinctive microRNA profiles relating to patient survival in esophageal squamous cell carcinoma. Cancer Res. 68: 26-33. http://dx.doi.org/10.1158/0008-5472.CAN-06-4418

Hack SP, Bruey JM and Koeppen H (2014). HGF/MET-directed therapeutics in gastroesophageal cancer: a review of clinical and biomarker development. Oncotarget 5: 2866-2880. http://dx.doi.org/10.18632/oncotarget.2003

Iwazawa T, Shiozaki H, Doki Y, Inoue M, et al. (1996). Primary human fibroblasts induce diverse tumor invasiveness: involvement of HGF as an important paracrine factor. Jpn. J. Cancer Res. 87: 1134-1142. http://dx.doi. org/10.1111/j.1349-7006.1996.tb03123.x

Kalantari HR (2009). Predictive factors for severe toxicity of sunitinib in unselected patients with advanced renal cell cancer. Br. J. Cancer 101: 1222-1223, author reply 1224. http://dx.doi.org/10.1038/sj.bjc.6605303

Liu WW, Wang HX, Yu W, Bi XY, et al. (2015). Treatment of silicosis with hepatocyte growth factor-modified autologous bone marrow stromal cells: a non-randomized study with follow-up. Genet. Mol. Res. 14: 10672-10681. http://dx.doi. org/10.4238/2015.September.9.7

Makino T, Yamasaki M, Takeno A, Shirakawa M, et al. (2009). Cytokeratins 18 and 8 are poor prognostic markers in patients with squamous cell carcinoma of the oesophagus. Br. J. Cancer 101: 1298-1306. http://dx.doi.org/10.1038/ s.j.bjc. 6605313

Nakamura T, Teramoto H and Ichihara A (1986). Purification and characterization of a growth factor from rat platelets for mature parenchymal hepatocytes in primary cultures. Proc. Natl. Acad. Sci. USA 83: 6489-6493. http://dx.doi. org/10.1073/pnas.83.17.6489

Noguchi T, Shibata T, Fumoto S, Sato T, et al. (2003). Detection of disseminated cancer cells in rib marrow of patients with esophageal cancer. Oncol. Rep. 10: 623-627.

Okawa T, Michaylira CZ, Kalabis J, Stairs DB, et al. (2007). The functional interplay between EGFR overexpression, hTERT activation, and p53 mutation in esophageal epithelial cells with activation of stromal fibroblasts induces tumor development, invasion, and differentiation. Genes Dev. 21: 2788-2803. http://dx.doi.org/10.1101/gad.1544507

Olumi AF, Grossfeld GD, Hayward SW, Carroll PR, et al. (1999). Carcinoma-associated fibroblasts direct tumor progression of initiated human prostatic epithelium. Cancer Res. 59: 5002-5011.

Parker RK, Dawsey SM, Abnet CC and White RE (2010). Frequent occurrence of esophageal cancer in young people in western Kenya. Dis. Esophagus 23: 128-135. http://dx.doi.org/10.1111/j.1442-2050.2009.00977.x

Pennathur A, Gibson MK, Jobe BA and Luketich JD (2013). Oesophageal carcinoma. Lancet 381: 400-412. http://dx.doi. org/10.1016/S0140-6736(12)60643-6

Ren Y, Cao B, Law S, Xie Y, et al. (2005). Hepatocyte growth factor promotes cancer cell migration and angiogenic factors expression: a prognostic marker of human esophageal squamous cell carcinomas. Clin. Cancer Res. 11: 61906197. http://dx.doi.org/10.1158/1078-0432.CCR-04-2553

Saeki H, Oda S, Kawaguchi H, Ohno S, et al. (2002). Concurrent overexpression of Ets-1 and c-Met correlates with a phenotype of high cellular motility in human esophageal cancer. Int. J. Cancer 98: 8-13. http://dx.doi.org/10.1002/ ijc. 10163

Genetics and Molecular Research 15 (3): gmr.15038583 
Schüssler MH, Skoudy A, Ramaekers F and Real FX (1992). Intermediate filaments as differentiation markers of normal pancreas and pancreas cancer. Am. J. Pathol. 140: 559-568.

Stoker M, Gherardi E, Perryman M and Gray J (1987). Scatter factor is a fibroblast-derived modulator of epithelial cell mobility. Nature 327: 239-242. http://dx.doi.org/10.1038/327239a0

Takada N, Yano Y, Matsuda T, Otani S, et al. (1995). Expression of immunoreactive human hepatocyte growth factor in human esophageal squamous cell carcinomas. Cancer Lett. 97: 145-148. http://dx.doi.org/10.1016/0304$\underline{3835(95) 03967-2}$

Trask DK, Band V, Zajchowski DA, Yaswen P, et al. (1990). Keratins as markers that distinguish normal and tumor-derived mammary epithelial cells. Proc. Natl. Acad. Sci. USA 87: 2319-2323. http://dx.doi.org/10.1073/pnas.87.6.2319

Wang C, You X, Jiang C, Jin C, et al. (2014). Hepatocyte growth factor upregulates nexilin gene expression in cardiomyocytes via JNK pathway. Genet. Mol. Res. 13: 4976-4982. http://dx.doi.org/10.4238/2014.July.4.12

Weng YR, Cui Y and Fang JY (2012). Biological functions of cytokeratin 18 in cancer. Mol. Cancer Res. 10: 485-493. http://dx.doi.org/10.1158/1541-7786.MCR-11-0222

Zhang QB, Gao YP, He JT, Zhang TT, et al. (2011). Establishment of a novel human esophageal squamous cell carcinoma cell line (ESC-410) and its partial biological characterization. Dis. Esophagus 24: 120-126. http://dx.doi.org/10.1111/ j.1442-2050.2010.01106.x

Genetics and Molecular Research 15 (3): gmr.15038583 